\title{
RASA SEBAGAI PRINSIP PERTAMA ONTOLOGI HARMONI DALAM PATHET PERGELARAN WAYANG
}

\author{
Reno Wikandaru \\ Fakultas Filsafat Universitas Gadjah Mada \\ Jl. Olahraga, Bulaksumur, Caturtunggal, Depok, Kabupaten Sleman, D.I. Yogyakarta 55281, Indonesia \\ E-Mail: renowikandaru@ugm.ac.id \\ Lasiyo \\ Fakultas Filsafat Universitas Gadjah Mada \\ Jl. Olahraga, Bulaksumur, Caturtunggal, Depok, Kabupaten Sleman, D.I. Yogyakarta 55281, Indonesia \\ E-Mail: lasiyo@ugm.ac.id
}

\author{
Suminto A. Sayuti \\ Fakultas Bahasa dan Seni, Universitas Negeri Yogyakarta \\ J1. Colombo No.1, Karang Malang, Caturtunggal, Depok, Kabupaten Sleman, Daerah Istimewa Yogyakarta 55281, \\ Indonesia \\ E-Mail: suminto1956@yahoo.co.id
}

\begin{abstract}
This study aims to find and critically analyze the first principle of harmony in the wayang performance's concept of pathet. The wayang performance's concept of pathet as a material object which is analyzed from the perspective of the ontology as a formal object. The methodical elements of the study used include interpretation, induction, and deduction, internal coherence, holistic, historical continuity, idealization, comparison, heuristics, inclusive or analogous language, and description. The results of the study indicate that pathet is a concept that has an important position in the performance of wayang. Philosophically, pathet has many function and meaning. First, pathet is a representation of the structure of wayang performances. Second, pathet is the reference to the sound space in musical instruments. Third, pathet is the atmosphere builder or atmosphere of wayang performances. Fourth, pathet is a guide to the mastermind in building the aesthetic of wayang performance. Pathet, in addition, to have a function also consist of philosophical meaning. First, pathet as an aesthetic manifestation in puppet shows. Second, pathet is a symbol of the stages in human life. Third, pathet as a representation of the cosmic cycle. The investigation of pathet from the perspective of ontology yields the following conclusions. First, the concept of pathet is a representation of the concept of harmony in wayang performance. "Rasa" is the first principle of harmony in the wayang performance's concept of pathet. This "rasa" has a spiritual dimension so that the ontology of harmony, in this case, is spiritualism. The dynamics of harmony moves with the law of "empan papan", towards the ultimate goal of reality, namely the perfection of life. Ontology of harmony in the pathet of wayang performances shows monistic-spiritualistic thinking.

Keywords:

pathet; wayang; ontology; monism; spiritualism
\end{abstract}

\begin{abstract}
Abstrak
Penelitian ini bertujuan untuk menemukan dan menganalisis secara kritis prinsip pertama harmoni dalam pathet pergelaran wayang. Peneliti di dalam menganalisis prinsip pertama ontologi harmoni ini menempatkan pathet pergelaran wayang sebagai objek material yang dianalisis dari sudut pandang ontologi sebagai objek formal. Unsur metodis pengkajian yang digunakan antara lain adalah interpretasi, induksi, dan deduksi, koherensi intern, holistika, kesinambungan historis, idealisasi, komparasi, heuristika, bahasa inklusif atau analogal, dan deskripsi. Hasil penelian menunjukkan bahwa pathet adalah sebuah konsep yang memiliki kedudukan penting di dalam pelaksanaan pertunjukan wayang. Secara filosofis, pathet memiliki fungsi dan makna. Pertama, pathet merupakan representasi tatanan atau struktur pertunjukan wayang. Kedua, pathet adalah acuan ruang bunyi di dalam karawitan pakeliran. Ketiga, pathet adalah pembangun suasana atau atmosfer pertunjukan wayang. Keempat, pathet adalah pedoman dalang di dalam membangun estetika pertunjukan wayang. Pathet di samping memiliki fungsi juga memiliki makna filosofis. Pertama, pathet sebagai manifestasi estetika di dalam pertunjukan wayang. Kedua, pathet merupakan simbolisasi tahap-tahap di dalam kehidupan manusia. Ketiga, pathet sebagai representasi siklus kosmik. Penyelidikan tentang pathet dari perspektif ontologi menghasilkan
\end{abstract}


beberapa kesimpulan sebagai berikut. Pertama, konsep pathet adalah representasi dari konsep harmoni di dalam pertunjukan wayang. Rasa adalah prinsip pertama harmoni di dalam pathet pergelaran wayang. Rasa ini memiliki dimensi spiritual sehingga ontologi harmoni dalam hal ini bercorak monistik-spiritualistik.

\section{Kata Kunci:}

wayang, pathet; wayang; ontologi; monisme; spiritualisme

DOI: $10.15575 /$ jw.v3i2.5629

Received: October 2018 ; Accepted: December 2018 ; Published: December 2018

\section{A. PENDAHULUAN}

Alam semesta dengan segala dinamika yang ada di dalamnya adalah misteri bagi manusia yang selalu mengundang tanda tanya. Bersamaan dengan keberadaan manusia di dunia, berbagai macam fenomena alam yang mengiringi perjalanan dunia, selalu saja menimbulkan rasa takjub dan pertanyaan yang tiada bertepi dalam benak manusia. Sejak ribuan tahun yang lalu, fenomena-fenomena tersebut selalu menimbulkan rasa takjub dan rasa heran sehingga manusia pun terpacu untuk memahami fenomena-fenomena tersebut. Berbagai cerita pun kemudian berkembang. Mitologi, kosmogoni, dan berbagai macam versi cerita pada akhirnya muncul sebagai 'pelarian' atau jawaban alternatif manusia atas segala fenomena alam tersebut. Seiring dengan perjalanan waktu, rasa ingin tahu manusia tersebut ternyata terus berkembang dan tidak lagi bisa dihentikan oleh cerita-cerita yang sulit dipahami dengan akal atau rasio manusia. Pada titik inilah, kehausan akan penjelasan yang rasional tersebut muncul dan melahirkan kajian yang kritis, radikal, spekulatif, dan tentu saja rasional sebagai jawaban atas berbagai macam pertanyaan manusia tersebut. Kajian inilah yang dinamakan dengan filsafat. Filsafat lahir sebagai kajian yang berusaha menjelaskan hakikat dari segala yang ada dan mungkin ada dengan mengandalkan rasio sebagai instrumen utamanya. Bertolak dari objek kajian filsafat yang mencakup segala hal tersebut, dapat dikatakan bahwa objek kajian filsafat sangat luas. Objek kajian filsafat ini pada perkembangannya dibagi ke dalam beberapa kajian yang lebih spesifik, antara lain metafisika atau ontologi; epistemologi; dan aksiologi sebagai cabang utama filsafat.

Metafisika sebagai salah satu cabang filsafat, memiliki kedudukan penting di dalam sistematika ilmu filsafat dan sekaligus menjadi salah satu cabang filsafat yang paling tua. Usianya dapat dikatakan sama tuanya dengan usia filsafat, khususnya filsafat Barat. Kajian metafisika yang nantinya disebut juga dengan istilah ontologi, dalam catatan sejarah filsafat sudah dimulai sejak para filsuf di masa Yunani Kuno memperkenalkan kajian tentang arkhe atau prinsip pertama dari segala sesuatu. Pertanyaan terbesar para filsuf pada masa itu adalah: apakah prinsip pertama dari segala sesuatu? Jawaban yang dikemukakan oleh para filsuf pun bermacam-macam. Thales $( \pm 624$ $546 \mathrm{SM}$ ) misalnya, menjawab bahwa hakikat terdalam realitas tersebut adalah air; Herakleitos ( \pm 540-480 SM) menjawab api; Phythagoras ( \pm 570-500 SM) menjawab bilangan; dan lain sebagainya. Sejak diperkenalkan oleh para filsuf Yunani Kuno tersebut, kajian metafisika sebagai kajian tentang hakikat terdalam realitas pun berkembang. Plato ( \pm 428-348 SM) misalnya, mengemukakan pemikirannya tentang dunia idea. Tidak lama setelah itu, Aristoteles $( \pm 384-$ 322 SM) menyusun kajian metafisika menjadi lebih sistematis. Berbagai istilah teknis dalam metafisika pun diperkenalkan oleh Aristoteles ${ }^{1}$. Sejak Aristoteles memperkenalkan metafisika tersebut, kajian metafisika semakin berkembang. Persoalan yang menjadi bahan kajian metafisika pun menjadi semakin

\footnotetext{
${ }^{1}$ Joko Siswanto, Metafisika Sistematik (Yogyakarta: Taman Pustaka Kristen, 2004), 3.
} 
kompleks. Metafisika, dalam sejarah filsafat, bahkan tercatat pernah menjadi 'primadona' dalam kajian filsafat, yaitu ketika abad pertengahan. Pada abad modern, metafisika mendapatkan sebutan baru, yaitu ontologi. Penggunaan istilah ontologi dalam kajian metafisika ini tidak dapat dilepaskan dari peran Christian Wolff (1679-1754) yang mempopulerkan istilah ontologi tersebut. Secara historis, istilah metafisika memang telah muncul terlebih dahulu, namun demikian kedua istilah tersebut memiliki karakteristik kajian yang sama karena dalam skema Wolff, ontologi pun sebenarnya juga bagian dari metafisika. Artinya, karakteristik kajian ontologi sama dengan karakteristik kajian metafisika. Sebagaimana dikemukakan oleh Joko Siswanto, skema Wolff tentang metafisika, umumnya juga sudah tidak diikuti oleh para pemikir kontemporer. Perbedaan antara ontologi dan metafisika tidak lagi menjadi persoalan. Metafisika disebut juga dengan ontologi, dan begitu pula sebaliknya. Metafisika juga mendapatkan sebutan baru, yakni sebagai cabang filsafat yang menyelidiki prinsip-prinsip pertama ${ }^{2}$. Peneliti dalam penelitian ini pun menyebut metafisika dan ontologi secara bergantian.

Seiring dengan perkembangan waktu, kajian ontologi berkembang semakin pesat. Pasang surut sebagai kajian yang kontroversial selalu dialami oleh ontologi. Berbagai macam kritik terhadap kajian ini juga selalu muncul, namun demikian hingga kini nyatanya ontologi masih menjadi salah satu kajian yang menarik untuk dibicarakan. Berbagai persoalan ontologi juga tidak kunjung selesai untuk dibahas. Hal ini tidak lain disebabkan karena persoalan ontologi atau metafisika bersifat implikatif, sebagaimana dikemukakan oleh Sontag ${ }^{3}$. Satu persoalan akan menimbulkan persoalan yang lain; jawaban atas persoalan yang satu akan melahirkan persoalan yang lain. Persoalan yang menjadi pokok bahasan ontologi terus

\footnotetext{
${ }^{2}$ Siswanto, Metafisika Sistematik, 6.

3 Frederick Sontag, Problems of Metaphysics (Scranton: Chandler Publishing Company, 1970), 18.
}

mengalami perkembangan seiring dengan perkembangan waktu. Persoalan-persoalan itu pun berkembang dan berimplikasi pada munculnya persoalan lain. Salah satu persoalan penting yang menurut peneliti sangat menarik untuk dibicarakan adalah persoalan harmoni.

Persoalan tentang harmoni ini menjadi menarik untuk dibicarakan setidaknya karena dua alasan. Pertama, konsep harmoni adalah konsep yang umum dikenal dalam perbincangan masyarakat awam (the man on the street). Kata harmoni, dalam kehidupan sehari-hari, sering disebut dan menjadi bahan perbincangan sehari-hari khususnya berkaitan dengan realitas sosial, misalnya dalam hubungan antara agama dan budaya ${ }^{4}$. Kata harmoni ini, meskipun bukan kata yang asing bagi masyarakat, namun demikian makna yang terkandung dalam istilah ini tidak banyak dipahami oleh orang pada umumnya. Setiap saat manusia bergulat untuk memahami arti kata harmoni. Berbagai macam ajaran atau petuah bijak untuk mewujudkan harmoni di dalam berbagai sendi kehidupan manusia juga dapat dijumpai di dalam banyak sumber. Kata "harmoni" seolah sudah menjadi kata yang umum, yang maknanya seakan-akan sudah diketahui dan dipahami dengan baik oleh setiap orang yang mendengarnya. Kenyataannya, namun demikian, merumuskan makna dari kata "harmoni" tersebut tidaklah mudah. Di sinilah letak permasalahan sebenarnya. Ketika istilah 'harmoni' menjadi istilah yang umum, dalam arti sudah umum digunakan di dalam komunikasi di masyarakat pada umumnya, dan bahkan menjadi kondisi yang selalu dicitacitakan dan berusaha untuk dicapai, maka seharusnya makna dari istilah tersebut dapat dipahami dengan baik. Kenyataannya yang terjadi tidaklah demikian. Merumuskan makna dan hakikat dari 'harmoni' bukanlah perkara yang mudah.

Alasan kedua yang membuat persoalan harmoni menarik untuk diperbincangkan dalam

\footnotetext{
${ }^{4}$ S. Supriyanto, "Harmoni Islam Dan Budaya Jawa Dalam Tafsir Alquran Suci Basa Jawi," Wawasan: Jurnal Ilmiah Agama Dan Sosial Budaya 3, no. 1 (June 30, 2018), 25, https://doi.org/10.15575/jw.v3i1.2578.
} 
perspektif ontologi adalah karena persoalan harmoni memiliki kaitan yang erat dengan persoalan lainnya, yaitu persoalan norma ontologis transendental. Persoalan harmoni sebenarnya bukanlah persoalan yang baru di dalam sejarah perkembangan ontologi. Persoalan ini telah menjadi perhatian para filsuf sejak lama. Pada masa Yunani kuno misalnya, persoalan harmoni telah muncul dalam pemikiran Pythagoras, dan muncul kembali pada perkembangan filsafat di masa modern, yaitu pada pemikiran Leibniz (1646-1716). Anton Bakker, dalam bukunya yang berjudul Ontologi atau Metafisika Umum (1992), memasukkan persoalan harmoni tersebut sebagai salah satu persoalan di dalam ontologi. Anton Bakker menyebutkan setidaknya delapan persoalan pokok di dalam ontologi. Persoalan -persoalan tersebut adalah: 1) persoalan otonomi dan relasi pengada; 2) sifatsifat pengada; 3) dinamika pengada; 4) kejasmanian dan kerohanian pengada; 5) kegiatan dan penyebaban pengada; 6) arti dan nilai pengada; 7) norma pengada; dan 8) persoalan tiada.

Anton Bakker mengemukakan bahwa harmoni adalah norma ontologis yang mengatasi segala macam pengada. Bagi setiap pengada mana pun, norma bagi tercapainya kepenuhan mengadanya adalah penghayatan harmoni maksimal dalam segala macam biporalitas struktural. Harmoni maksimal itu merupakan norma ontologis-transendental bagi pengada, yaitu norma definitif, final, ultima, dan total ${ }^{5}$. Pandangan Bakker ini, meskipun tampaknya cukup memberikan jawaban atas persoalan norma ontologis transendental, bagi peneliti masih dapat dikembangkan untuk menjawab persoalan tentang norma ontologis transendental. Menurut peneliti, masih ada persoalan yang fundamental tentang apa yang

\footnotetext{
5 Anton Bakker, Ontologi Atau Metafisika Umum (Yogyakarta: Kanisius, 1992), 204.

6 Tim Filsafat Wayang, Filsafat Wayang Sistematis (Jakarta: Senawangi, 2016), 11.

7 Koentjaraningrat, Kebudayaan, Mentalitas, Dan Pembangunan (Jakarta: Gramedia Pustaka Utam, 2004), 2.
}

dimaksud dengan harmoni tersebut. Jawaban atas persoalan tersebut, di sisi yang lain menjadi penting karena akan menjadi jawaban atas persoalan tentang hubungan antara semua tataran pengada. Jawaban atas persoalan harmoni juga akan menjadi jawaban tentang persoalan kuantitas realitas, kualitas realitas, dan implementasinya terhadap kehidupan, termasuk pada keteraturan kosmos.

Berdasarkan pertimbangan di atas, oleh karenanya menyelidiki makna yang dikandung oleh istilah 'harmoni' adalah upaya yang penting untuk dilakukan bukan hanya dalam rangka membangun pemahaman tentang istilah tersebut tetapi juga dalam rangka menyajikan pandangan alternatif tentang harmoni. Penyelidikan ini dapat dilakukan dari berbagai sudut pandang. Salah satunya adalah dari sudut pandang pemikiran yang berkembang di dalam adat istiadat dan budaya kehidupan masyarakat Indonesia. Pemikiran Indonesia, sebagai bagian dari semesta pemikiran Timur, menempatkan harmoni sebagai postulat, berbeda dengan pemikiran Barat yang cenderung mengabaikan harmoni ${ }^{6}$. Kebudayaan dari berbagai macam suku bangsa di Indonesia tersebut tersebar dalam berbagai wujud, baik fisik, aktivitas sosial, atau gagasan; dan terpilah ke dalam tujuh unsur, yaitu sistem religi dan kepercayaan, sistem pengetahuan, sistem organisasi sosial, sistem teknologi, sistem mata pencaharian hidup, bahasa, dan kesenian ${ }^{7}$. Kebudayaan yang tumbuh dan berkembang di Indonesia tersebut menjadikan Indonesia sebagai bangsa yang memiliki kemajemukan kultural yang tinggi. ${ }^{8}$ Berbagai macam budaya tersebut, di tengah fenomena globalisasi dan banjir budaya pop-kontemporer saat ini, seolah diuji. Ada yang mampu bertahan di tengah derasnya aliran kebudayaan dari luar yang masuk ke Indonesia; namun

8 Shely Cathrin, "Tinjauan Filsafat Kebudayaan Terhadap Upacara Adat Bersih-Desa Di Desa Tawun, Kecamatan Kasreman, Kabupaten Ngawi, Jawa Timur," Jurnal Filsafat 27, no. 1 (2017), 31, https://doi.org/10.22146/jf.22841. 
tidak sedikit pula yang hilang karena tidak lagi didukung oleh masyarakatnya. Ada satu bentuk kesenian yang memiliki banyak keistimewaan di antara sekian banyak kebudayaan yang mampu bertahan di tengah globalisasi dan hiruk pikuk budaya kontemporer saat ini. Kesenian tersebut adalah wayang.

Wayang sangat menarik untuk dijadikan sebagai bahan kajian karena wayang bukanlah pertunjukan yang menawarkan tontonan semata, namun juga ada makna yang terkandung di dalamnya. ${ }^{9}$ Wayang memang mengangkat cerita-cerita yang dekat dengan persoalan keseharian manusia sehingga disebut juga dengan wewayangane ngaurip atau bayangan kehidupan ${ }^{10}$. Wayang, namun demikian juga menjanjikan makna yang lebih mendalam. Suatu cerita lakon wayang yang dipentaskan oleh seorang dalang ternyata memiliki makna simbolis, baik secara perseorangan maupun kelompok ${ }^{11}$. Pergelaran wayang sebagai objek kajian filosofis mengandung pandangan-pandangan filsafat akademik, baik pandangan metafisika atau ontologi, epistemologi, maupun aksiologi ${ }^{12}$.

Berbagai macam keistimewaan yang terdapat di dalam pergelaran wayang tersebut adalah hal strategis yang memiliki peluang untuk dikaji lebih lanjut. Fakta bahwa wayang mampu bertahan hingga sekarang, menunjukkan bahwa ada sesuatu dalam wayang; ada nilai lebih dalam wayang yang membuatnya menjadi salah satu pertunjukan populer di masyarakat. Wayang telah ada, tumbuh, dan berkembang sejak lama serta memiliki daya tahan dan daya kembang yang teruji dalam menghadapi tantangan dari waktu ke waktu ${ }^{13}$. Hal inilah yang menurut peneliti bisa menjadi titik tolak posisi strategis filsafat wayang di dalam menjawab persoalanpersoalan ontologi, salah satunya persoalan tentang harmoni sebagaimana yang disinggung di atas.

Pemikiran ontologis di dalam wayang, dapat digali dari simbol-simbol yang melingkupi hampir seluruh unsur di dalam pergelaran wayang. Peneliti dalam mengkaji persoalan hakikat harmoni tersebut, memfokuskan objek penelitian pada pathet pergelaran wayang karena pathet adalah konsep yang memiliki kedudukan penting dalam pergelaran wayang $^{14}$. Pathet berkaitan dengan pembabakan dalam struktur pergelaran wayang, sekaligus juga berkaitan dengan tatanan yang ada pada pertunjukan wayang tersebut. Pathet juga memiliki kaitan yang erat dengan karawitan atau iringan yang menyertai pertunjukan wayang, sehingga dalam pathet juga tersirat pandangan tentang harmoni yang berkaitan dengan keseluruhan pelaksanaan pergelaran wayang. Pathet dalam konstelasi pertunjukan wayang secara umum, menempati peran yang sangat penting. Struktur pergelaran wayang terbagi ke dalam tiga pathet, yaitu pathet nem, pathet sanga, dan pathet manyura. Masing-masing pathet memiliki karakter dan pembabakannya masing-masing. ${ }^{15}$ Di dalam pathet tersebut tersirat konsep waktu, yang sebenarnya menarik untuk dibahas. Sayangnya, berbagai macam penelitian tentang wayang, bahkan penelitian tentang filsafat wayang sendiri, belum banyak membahas tentang peran

\footnotetext{
${ }^{9}$ Makna pertunjukan Wayang dalam dakwah lihat Bayu Anggoro, “'Wayang Dan Seni Pertunjukan' Kajian Sejarah Perkembangan Seni Wayang Di Tanah Jawa Sebagai Seni Pertunjukan Dan Dakwah," JUSPI (Jurnal Sejarah Peradaban Islam) 2, no. 2 (2018): 122, https://doi.org/10.30829/j.v2i2.1679.

Penelitian pertunjukan wayang kaitannya dengan Pendidikan budi pekerti lihat Cahya, "Nilai, Makna, Dan Simbol Dalam Pertunjukan Wayang Golek Sebagai Representasi Media Pendidikan Budi Pekerti,” Panggung 26, no. 2 (2017), https://doi.org/10.26742/panggung.v26i2.170.

${ }^{10}$ Solichin, Falsafah Wayang (Jakarta: Senawangi, 2011), 6 .
}

\footnotetext{
11 Slamet Sutrisno et al., Filsafat Wayang (Jakarta: Senawangi, 2009), 16.

${ }^{12}$ Tim Filsafat Wayang, Filsafat Wayang Sistematis, 13.

${ }^{13}$ Tim Filsafat Wayang, Filsafat Wayang Sistematis, 9.

${ }^{14}$ S. Hastanto, "The Conce Pt of Pathet in Central Javanese Gamelan Music" (Durham University, 1985), http://etheses.dur.ac.uk/1214/.

${ }^{15}$ W. N. C. Rich, "Nyalap-Nyaur: Model Tatakelola Pergelaran Wayang Jekdong Dalam Hajatan Tradisi JawaTimuran," Humaniora 24, no. 2 (2012): 175-86.
} 
pathet dalam pergelaran wayang. Berdasarkan kenyataan tersebut, penelitian ini mengeksplorasi lebih jauh eksistensi, peran, fungsi, dan hakikat pathet pergelaran wayang, dan selanjutnya menganalisis prinsip pertama harmoni yang terdapat dalam pathet tersebut dari perspektif ontologi. Kajian ini diharapkan menjadi pemikiran alternatif dalam diskursus tentang harmoni.

Adapun unsur metodis yang digunakan di dalam penelitian ini adalah interpretasi, induksi, dan deduksi, koherensi intern, holistika, kesinambungan historis, idealisasi, komparasi, heuristika, bahasa inklusif atau analogal, dan deskripsi. Metode interpretasi digunakan untuk mengungkap makna filosofis di balik konsep harmoni pathet dalam pergelaran wayang dan keterkaitannya dengan pandangan dunia masyarakat Jawa. Metode Induksi digunakan untuk menggeneralisasi halhal yang ditemukan dalam setiap data penelitian guna mendapatkan kesimpulan yang bersifat umum. Deduksi digunakan untuk keperluan eksplisitasi hal-hal yang ditemukan dalam konsep harmoni pathet pergelaran wayang dan penerapannya pada hal-hal yang khusus. Koherensi intern diperlukan untuk membangun pemahaman yang utuh di antara temuan-temuan yang terkait dengan hakikat pathet dalam pergelaran wayang dan aspekaspek ontologis yang ditemukan dalam konsep pathet tersebut. Metode holistik digunakan untuk menganalisis konsep pathet dalam pergelaran wayang secara menyeluruh. Pathet tidak hanya dikaitkan dengan struktur pergelaran wayang, tetapi juga dikaitkan dengan beberapa aspek yang terkait dengan pelaksanaan pergelaran wayang tersebut, antara lain dengan karawitan pakeliran dan pandangan dunia masyarakat Jawa. Unsur metodis berupa kesinambungan historis sangat diperlukan karena konsep pathet adalah konsep yang terlahir dari pergulatan manusia dengan dunianya melalui budaya yang berkembang dari waktu ke waktu. Memahami penggunaan istilah tersebut di sepanjang sejarah karenanya adalah satu hal penting yang harus dilakukan guna mendapatkan pemahaman yang komprehensif tentang penggunaan konsep pathet tersebut. Metode idealisasi digunakan untuk memahami kenyataan secara lebih mendalam ${ }^{16}$. Melalui metode ini, peneliti berusaha merekonstruksi satu gambaran atau struktur yang murni dan konsekuen tentang konsep pathet dalam pergelaran wayang. Pada prakteknya, metode komparasi ini juga digunakan dalam upaya membandingkan data yang satu dengan yang lain; serta dengan berbagai konsep terkait yang berkembang dalam pemahaman masyarakat Jawa. Heuristika adalah metode untuk menemukan jalan baru secara ilmiah, untuk memecahkan masalah ${ }^{17}$. Bahasa inklusif atau analogal digunakan untuk merumuskan berbagai temuan penelitian ke dalam satu konsep inklusif yang meliputi semua aspek. Deskripsi, digunakan untuk mendapatkan pemahaman yang lebih mantap tentang konsep harmoni pathet pergelaran wayang dalam perspektif ontologi.

\section{B. HASIL DAN PEMBAHASAN \\ 1. Ontologi sebagai Kajian atas "Prinsip Pertama"}

Secara etimologis, istilah ontologi, yang dalam bahasa Inggris disebut ontology, adalah bentukan dari dua kata, yakni "ontos" dan "logos". Istilah "ontos" adalah bentuk genetif dari kata Yunani "on", dan bentuk netral dari kata tersebut adalah "oon". Kata ini berasal dari bahasa Yunani "to on hei on" yang berarti "yang-ada sebagai yang-ada"18. Kata Yunani "logos" sering diartikan sebagai "tuturan" atau "ilmu". Berdasarkan arti dari dua kata tersebut, ontologi bisa diartikan sebagai ilmu atau kajian mengenai yang-ada sebagai yang-ada ( $a$ being as being; being qua being). Menurut Bakker, ontologi bisa diartikan sebagai kajian atau ilmu yang mempelajari tentang "yang-ada yang

17 Bakker and Zubair, Metodologi Penelitian Filsafat, 52.

${ }^{18}$ Siswanto, Metafisika Sistematik, 2. 
umum", sesuai dengan makna kata "ontos" sebagai bentuk generatif dari "on" di atas ${ }^{19}$.

Secara historis, Christian Wolff (1679-1754) adalah tokoh yang memperkenalkan istilah "ontologi". Wolff, di dalam bukunya Ontology, membagi filsafat ke dalam dua bagian, yakni filsafat praktis dan filsafat teoretis. Filsafat praktis dibagi ke dalam tiga bagian, yakni etika, ekonomi, dan politik; sedangkan filsafat teoretis, yang disebut dengan metafisika, dibagi ke dalam dua bagian, yakni metafisika umum dan metafisika khusus. Metafisika umum disebut dengan istilah "ontologi", sedangkan metafisika khusus dibagi lagi ke dalam tiga bagian, yakni psikologi rasional (rational psychology), kosmologi (cosmology), dan teologi natural (natural theology) ${ }^{20}$. Sesuai dengan klasifikasinya tersebut, ontologi merupakan ilmu yang menelaah "yang-ada sebagai yang-ada" dengan perspektif yang lebih luas, sesuai dengan nama yang ia gunakan, yakni metafisika umum ${ }^{21}$.

Secara terminologis, istilah ontologi dipahami secara bermacam-macam oleh para tokoh. Aristoteles, semula memberikan pengertian terhadap istilah metafisika yaitu sebagai cabang filsafat yang mengkaji yangada sebagai yang-ada (being qua being). Menurut sudut pandang ini, untuk mengkaji satu hal dari sudut pandang metafisika, harus terlebih dahulu disepakati bahwa hal tersebut termasuk dalam yang-ada (being) ${ }^{22}$. Frederick Sontag, memahami metafisika sebagai filsafat pokok yang menelaah prinsip pertama atau the first principle ${ }^{23}$. Menurut perspektif Sontag, kajian metafisika atas satu persoalan berarti mencari prinsip pertama dalam persoalan tersebut. Kajian ini, meskipun tidak bisa diidentikkan dengan penyelidikan tentang arkhe di masa Yunani Kuno, tapi corak penyelidikannya memiliki kesamaan. Mengkaji metafisika moral, berarti mengkaji prinsip pertama dalam moral; metafisika ekonomi, berarti mengkaji prinsip pertama dalam ekonomi; dan seterusnya. Satu definisi yang hampir sama dengan definisi yang dikemukakan oleh Sontag di atas, adalah definisi yang dikemukakan oleh C.A. van Peursen. Sebagaimana dikutip oleh Joko Siswanto $^{24}$, van Peursen mendefinisikan metafisika sebagai cabang filsafat yang mengkaji persoalan mengenai akar terdalam dari segala yang ada. Pemikiran Peursen mengenai metafisika tersebut bisa dikatakan merupakan gabungan dari batasan yang dikemukakan oleh Aristoteles dan Frederick Sontag karena "akar terdalam" yang dimaksudkan oleh van Peursen di atas, mengakomodasi "prinsip pertama" yang dimaksudkan oleh Sontag, sedangkan penegasan mengenai yang-ada sebagai objek material metafisika, sebagaimana yang dimaksudkan oleh Aristoteles, juga ditegaskan oleh Van Peursen dalam definisi yang ia kemukakan tersebut.

Metafisika dan ontologi adalah dua istilah yang memang tidak dapat dipisahkan satu dengan yang lain. Istilah metafisika telah dikenal terlebih dahulu dalam dunia filsafat ketika Andronikos dari Rhodes menyusun karya-karya Aristoteles. Sementara istilah ontologi baru diperkenalkan oleh Christian Wolff sekitar abad ke-16. Kesan perbedaan pengertian di antara kedua istilah tersebut tidak dapat dipungkiri memang ada, yakni semenjak Wolff membagi metafisika menjadi dua cabang, yaitu metafisika umum dan metafisika khusus. Kim dan Sosa, dalam A Companion to Metaphysics, juga menuliskan bahwa sekarang istilah ontologi hanya dipahami sebagai nama lain dari metaphysica generalis atau metafisika umum $^{25}$. Kedua istilah tersebut, namun demikian bukan berarti memiliki perbedaan. Keduanya justru tidak dapat dipisahkan karena

\footnotetext{
${ }^{23}$ Siswanto, Metafisika Sistematik, 6.

${ }^{24}$ Siswanto, Metafisika Sistematik, 7.

25 Jaegwon Kim and Ernest Sosa, eds., A Companion to Metaphysics (Oxford: Blackwell Publishing, 1995), 373.
} 
sebagaimana ditelusuri dari segi etimologis di atas, keduanya memiliki objek material yang sama, yaitu "yang-ada" atau "being. Baik metafisika maupun ontologi sama-sama mengkaji "yang ada" sebagai "yang ada". Sutan Takdir Alisjahbana (STA), dalam Pembimbing Ke Filsafat Metafisika (1967), menunjukkan eratnya hubungan kedua bidang kajian tersebut sebagai berikut.

Sekalijan aliran jang kita sebut ini, jang mengenai kebenaran jang tersembunji di balik sekalian pendjelmaan, jang mengenai hakekat kenjataan jang kita hadapi, disebut orang aliran-aliran metafisika, atau lebih khusus lagi aliran ontologi, jang hendak mengetahui sifat dan keadaan kebenaran jang terachir dari pada kenjataan ${ }^{26}$.

Berdasarkan kutipan STA, tampak bahwa metafisika dengan ontologi adalah dua bidang kajian yang memiliki ciri yang sama, yaitu dalam bahasa STA - berusaha menyelidiki sifat dan keadaan kebenaran yang terakhir dari kenyataan. Ontologi dengan kata lain adalah bidang kajian yang menempatkan kenyataan sebagai objek material atau sebagai lapangan penyelidikan dengan tujuan untuk mencari sifat dan keadaan yang sebenar-benarnya dari kenyataan tersebut. Mengkaji satu hal dari sudut pandang ontologi, artinya menempatkan satu hal tersebut sebagai kenyataan atau sebagai being yang kemudian berusaha dicari sifat dan keadaan yang sebenarnya dari satu hal tersebut.

Sebanyak apa pun definisi yang dikemukakan, ontologi tetap saja merupakan kajian atau ilmu yang dipahami secara berbedabeda. Apabila ditarik pada tataran yang lebih umum, ada persamaan yang bisa diambil dari definisi yang berbeda-beda tersebut, yakni menyangkut objek material dan formal dari ontologi tersebut. Berkaitan dengan objek material, tentunya bisa disepakati bahwa objek kajian ontologi adalah "segala yang-ada". Sedangkan berkaitan dengan objek formal ontologi, "segala yang-ada" tersebut dianalisis hingga ditemukan sisi-sisi terdalam atau hakikatnya. Pertanyaan yang kemudian dapat dikemukakan adalah: lalu, apa metode yang dapat digunakan untuk sampai pada sisi terdalam atau hakikat realitas tersebut?

Salah satu karya yang memberikan penjelasan rinci tentang ontologi dan cara untuk sampai pada pemahaman tentang hakikat realitas tersebut dapat dijumpai dalam buku Anton Bakker yang berjudul Ontologi atau Metafisika Umum (1992). Bakker dalam buku tersebut mendefinisikan istilah ontologi sebagai cabang filsafat yang menyelidiki dan menggelar gambaran umum tentang struktur realitas yang berlaku mutlak dan umum. Definisi ini menyiratkan sekaligus dua fokus kajian ontologi. Pertama objek ontologi adalah realitas. Sebagaimana dikemukakan oleh Anton Bakker, kedudukan realitas sebagai bidang kajian ontologi ini menjadikan ontologi sebagai bidang kajian yang memiliki ruang lingkup yang luas karena 'realitas' mencakup segala yang ada maka segala yang ada dapat menjadi objek kajian ontologi. Hal ini sejalan dengan penelusuran etimologis dari istilah ontologi di atas. Hal kedua yang dapat diambil dari pengertian ontologi yang dikemukakan oleh Bakker adalah tentang "hukum-hukum" realitas yang dimaksudkan tersebut, yakni menyangkut keadaan dan dinamika yang dialami oleh realitas. Upaya untuk 'membongkar' struktur realitas yang berlaku mutlak dan umum sebagaimana dikemukakan oleh Bakker di atas, dilakukan dengan serangkaian metode atau langkah-langkah penyelidikan yang menuju pada hakikat terdalam dari realitas.

Berdasarkan uraian tentang pengertian ontologi di atas, dapat disimpulkan bahwa istilah "ontologi" bersangkutan dengan makna "hakikat realitas". Hal ini tidak lain berkaitan dengan sifat dan karakter kajian ontologi itu sendiri yang sebagaimana dikemukakan oleh Bakker, adalah cabang filsafat yang berusaha menggelar gambaran umum tentang struktur realitas yang berlaku mutlak dan umum. Sesuai dengan uraian tentang ontologi di atas,

\footnotetext{
${ }^{26}$ Sutan Takdir Alisjahbana, Pembimbing Kefilsafat Metafisika (Jakarta: Dian Rakjat, 1967), 19.
} 
penelitian tentang harmoni pathet pergelaran wayang dalam perspektif ontologi ini akan menempatkan wayang sebagai realitas, yang selanjutnya akan difokuskan pada konsep tentang pathet. Harmoni dalam pathet pergelaran wayang tersebut akan dianalisis dari sudut pandang ontologi, dengan harapan dapat ditemukan dimensi-dimensi ontologis dalam konsep pathet khususnya berkaitan dengan konsep harmoni sebagai norma ontologis transendental.

Penelitian ini nantinya akan menggunakan sudut pandang pemikiran ontologi sebagaimana yang dikemukakan oleh Bakker. Adapun ontologi Anton Bakker dipilih karena Bakker memberikan langkah-langkah yang terperinci tentang analisis ontologis yang dilakukan terhadap berbagai tataran realitas. Menurut Bakker, titik tolak dalam analisis ontologi adalah kenyataan. Kenyataan yang tersedia adalah data bagi ontologi ${ }^{27}$. Guna membongkar gambaran umum tentang struktur realitas tersebut, ontologi memulainya dengan menempatkan manusia dan dunia sebagai bahan awal refleksi. Manusia dipilih sebagai titik tolak awal bagi analisis ontologi karena manusia memiliki kesadaran akan dirinya sendiri. Manusia oleh karenanya adalah kunci bagi pemahaman kenyataan. Struktur realitas yang berlaku mutlak dan umum untuk segala yang ada tersebut 'dibongkar' dengan bertolak dari enam pertanyaan kunci, sebagaimana peneliti sarikan dari buku Ontologi atau Metafisika Umum (1992) yaitu: 1) otonomi dan relasi pengada, yang berhubungan dengan pertanyaan tentang kuantitas realitas; 2) sifatsifat pengada; 3) dinamika pengada, yaitu mencakup awal dan akhirnya; 4) kejasmanian dan kerohanian pengada, mencakup kualitas realitas; 5) kegiatan dan penyebaban pengada; 6) arti dan nilai pengada; dan 7) norma pengada. Ketujuh persoalan ontologi tersebut bukanlah persoalan yang terpisah satu dengan yang lain. Persoalan-persoalan tersebut bersifat implikatif, dalam arti jawaban atas pertanyaan yang satu akan membawa pada pertanyaan yang lain.

Penelitian ini menempatkan pathet pergelaran wayang sebagai objek material atau lapangan penyelidikan penelitian. Pathet tersebut nantinya akan diuraikan pengertian dan maknanya dalam keseluruhan pergelaran wayang. Berdasarkan pengertian dan makna pathet dalam pergelaran wayang tersebut, kemudian akan dirumuskan konsep harmoni di dalam pathet tersebut yang kemudian akan dianalisis dari sudut pandang ontologi Anton Bakker, dengan bertolak dari pertanyaanpertanyaan di atas. Hasil yang diharapkan dari penelitian ini adalah berupa pengertian tentang hakikat harmoni dalam pathet pergelaran wayang yang kemudian akan direlevansikan dengan persoalan kohesivitas sosial di Indonesia

\section{Makna Filosofis Pathet Pergelaran Wayang}

Istilah pathet adalah istilah yang berkaitan dengan dua hal. Pertama, berkaitan dengan struktur pertunjukan wayang secara umum; dan kedua, berkaitan dengan iringan karawitan yang menjadi bagian yang tidak terpisahkan dari pergelaran wayang. Sebagai bagian dari struktur pertunjukan wayang, pathet menunjukkan struktur pergelaran yang sirkuler. Pergelaran wayang dimulai dari keadaan yang tenang dan damai dan kembali kepada keadaan yang tenang dan damai dalam situasi yang berbeda ${ }^{28}$. Sebagaimana yang dikemukakan oleh Hazim Amir dalam bukunya yang berjudul Nilai-nilai Etis dalam Pewayangan $^{29}$, struktur pergelaran wayang yang demikian tersebut adalah struktur pergelaran kreasi Jawa. Struktur pergelaran tersebut berkaitan dengan siklus kosmos yang juga paralel dengan kejiwaan manusia ${ }^{30}$. Berdasarkan uraian tersebut, dapat disimpulkan bahwa struktur pergelaran wayang

\footnotetext{
${ }^{29}$ Hazim Amir, Nilai-Nilai Etis Dalam Pewayangan (Jakarta: Pustaka Sinar Harapan, 1991).

${ }^{30}$ Tim Filsafat Wayang, Filsafat Wayang Sistematis, 230.
} 
dengan ketiga pathet-nya tersebut tidak hanya berdimensi estetis, dalam arti tidak hanya berkaitan dengan struktur dramatik pertunjukan wayang saja, tetapi juga berdimensi kosmologis, yaitu berkaitan dengan harmoni alam semesta dan kejiwaan manusia. Harmoni ini dalam pemahaman masyarakat Jawa disebut dengan harmoni makrokosmos atau jagad gedhe dan mikrokosmos atau jagad cilik ${ }^{31}$.

Soetarno, dkk. dalam buku yang berjudul Estetika Pedalangan, menguraikan pathet tersebut dalam pembahasan tentang karawitan pakeliran. Karawitan pakeliran di dalam pergelaran wayang tradisional menandai pergantian wilayah nada yang membingkai struktur lakon, yaitu pathet nem (sekitar pukul 21.00-24.00); pathet sanga (sekitar pukul 00.00-03.00); pathet manyura (sekitar pukul 03.00-06.00) $)^{32}$. Berdasarkan uraian Soetarno dkk. tersebut dapat diketahui bahwa istilah pathet dalam pergelaran wayang memiliki kaitan erat dengan karawitan pakeliran. Soetarno dkk., namun demikian, dalam hal ini hanya menggunakan istilah pathet untuk menyebut wilayah nada dalam karawitan pakeliran, yang berhubungan dengan penanda waktu pelaksanaan pergelaran wayang sebagaimana dikemukakan di atas. Sumarsam, dalam bukunya yang berjudul Hayatan Gamelan, Kedalaman Lagu, Teori, dan Perspektif (2002) menguraikan bahwa setiap pathet mempunyai kekhususan waktu kapan ia dimainkan dalam pertunjukan gamelan karena hubungan antara pathet, waktu, dan suasana mempunyai makna yang sangat penting untuk musisi ataupun penonton ${ }^{33}$.

Penjelasan yang lebih memadai tentang istilah pathet dalam pergelaran wayang dapat ditemukan dalam buku berjudul Falsafah Wayang (2011), yang ditulis oleh Solichin. Sebagaimana yang dikemukakan oleh Solichin, pathet memang memiliki peran yang penting

\footnotetext{
${ }^{31}$ Franz Magnis-Suseno, Etika Jawa, Sebuah Analisa Falsafi Tentang Kebijaksanaan Hidup Jawa (Jakarta: Gramedia Pustaka Utama, 2001), 118.

32 Soetarno, Sunardi, and Sudarsono, Estetika Pedalangan (Surakarta: Institut Seni Indonesia (ISI) Surakarta dan CV. Adji, 2007), 59.
}

dalam keseluruhan pergelaran wayang. Ada beberapa definisi tentang pathet yang dikemukakan oleh beberapa tokoh. Menurut Mantle Hood, pathet adalah suatu sistem yang mengatur tentang kedudukan dan fungsi nada. Berbeda halnya dengan definisi yang diajukan oleh Ki Hadjar Dewantara. Menurut Ki Hadjar Dewantara, pathet adalah rakitan suara yang merupakan bagian dari satu-satu laras sebagai daerah bergeraknya lagu hingga akhirnya berkesan serta menimbulkan perasaan tertentu ${ }^{34}$. Berdasarkan dua definisi yang dikemukakan di atas, dapat dilihat bahwa pathet memang berkaitan dengan karawitan pakeliran, sebagaimana dikemukakan oleh Soetarno di atas, namun demikian pathet sejatinya tidak hanya terbatas pada persoalan tentang karawitan pakeliran saja. Pathet mengacu pada dua hal sekaligus. Pertama, pathet berkaitan dengan pembabakan dalam pergelaran wayang; dan kedua, pathet juga berkaitan dengan makna yang terkandung di dalam pergelaran wayang secara umum. Terkait dengan persoalan yang pertama, yaitu pathet sebagai bentuk pembabakan dalam pergelaran wayang, dapat dilihat dari pembagian struktur pergelaran wayang menjadi tiga bagian: pathet nem, pathet sanga, dan pathet manyura. Pembagian durasi waktunya adalah sebagaimana yang dikemukakan oleh Soetarno dkk., sebelumnya. Pathet nem berlangsung sekitar pukul 21.00 24.00; pathet sanga berlangsung sekitar pukul 00.00 - 03.00); pathet manyura berlangsung sekitar pukul 03.00 - 06.00 (Soetarno, dkk., 2007: 59). Pathet nem menggambarkan suasana yang netral; pathet sanga menggambarkan suasana yang agak tegang; sedang pathet manyura menggambarkan suasana yang telah berubah menjadi dinamik yang menuntut penyelesaian ${ }^{35}$.

\footnotetext{
${ }^{33}$ Sumarsam, Hayatan Gamelan, Kedalaman Lagu, Teori, Dan Perspektif (Surakarta: STSI Press Surakarta, 2002), 117.

${ }^{34}$ Sutrisno et al., Filsafat Wayang.

${ }^{35}$ S. Haryanto, Pratiwimba Adhiluhung, Sejarah Dan Perkembangan Wayang (Jakarta: Djambatan, 1988), 5.
} 
Pada saat pathet nem, gendhing yang disajikan untuk mengiringi pergelaran wayang adalah gendhing ber-pathet nem untuk titi nada slendro; dan gendhing ber-pathet lima untuk nada pelog. Seleh laras untuk pathet nem sangatlah lengkap, yaitu gong 6,5,3, dan 2. Di antara pathet yang lain, pathet nem adalah pathet dengan pilihan seleh nada terbanyak. Rasa gendhing yang disajikan juga dinamis ${ }^{36}$. Oleh karena seleh nada yang banyak ini, karakter dari pathet nem ini menjadi sukar untuk dijelaskan. Lain halnya dengan pathet sanga. Pada saat pergelaran wayang memasuki pathet sanga, gendhing yang disajikan adalah gendhing dengan pathet sanga untuk titi nada slendro, dan gendhing dengan pathet nem untuk titi nada pelog. Pada pathet sanga ini, seleh nada umumnya ada di nada 1 dan $5^{37}$. Nada 5 (lima) dan 1 (barang) menjadi nada yang paling penting di pathet sanga ${ }^{38}$. Secara musikal, gedhing-gendhing dengan pathet sanga bernuansa sepi nglangut dan tenang stabil. Adegan yang biasanya muncul pada saat pathet sanga ini adalah adegan pertapan, yaitu ketika seorang pertapa dihadap oleh seorang ksatria dengan para embannya ${ }^{39}$. Babak terakhir dalam pergelaran wayang adalah pathet manyura. Pada saat pergelaran wayang memasuki pathet manyura, gendhing-gendhing yang disajikan untuk titi nada slendro, adalah gendhing ber-pathet manyura, dan gendhing ber-pathet barang untuk titi nada pelog. Nada penting dalam pathet manyura ini adalah nada 6 (nem) dan 2 (gulu). Seleh nada pada saat pathet manyura ini adalah nada 6,3, dan 7 atau 1 dengan nada dasar $3^{40}$.

Sebagaimana dikemukakan sebelumnya, menurut Solichin pembagian pathet dalam pergelaran wayang menjadi tiga, tidak hanya berkaitan dengan titi nada yang digunakan dalam karawitan pakeliran yang mengiringi pertunjukan wayang, tetapi juga berkaitan dengan makna pertunjukan wayang secara keseluruhan. Pertunjukan wayang, sesungguhnya adalah semesta simbol yang kompleks. Hampir semua hal yang terdapat dalam pergelaran wayang merupakan simbol yang kaya akan makna. Termasuk juga halnya dengan pathet ini. Baik pathet nem, pathet sanga, maupun pathet manyura merupakan simbol yang menyiratkan makna. Pathet nem, adalah simbol dari karakter anak remaja serta pemuda yang belum mencapai kemapanan olah pikir. Pathet sanga, adalah simbol dari tahapan dalam hidup manusia sebagai awal kesadaran manusia mencapai pencerahan hidup. Ketika manusia sudah sampai pada kesadaran hakikat hidup maka ia akan menjadi prawira atau berani. Makna ini dalam pergelaran wayang disimbolkan dengan adegan perang kembang, yaitu adegan ketika ksatria mampu mengalahkan empat macam raksasa sebagai simbol dari empat nafsu dalam diri manusia ${ }^{41}$. Pathet manyura, sebagai tahapan paling akhir dalam pergelaran wayang, juga merupakan simbol dari situasi manusia menjelang akhir hidupnya. Dari segi bahasa, kata "manyura" sinonim dengan kata "merak" yang berkaitan dengan konsep "marak" atau menghadap. Makna dari tahapan ini adalah bahwa masa tua itu adalah masa-masa ketika manusia belajar untuk meninggalkan nikmatnya duniawi. Pada tahapan ini, manusia seharusnya telah condong pada kebenaran dan mampu menjadi manusia utama yang tinggi tingkat pengendalian dirinya sehingga segala sikap dan tindakannya tidak pernah lepas dari kesadarannya akan perintah Tuhan $^{42}$.

\section{Hakikat Harmoni dalam Pathet Pergelaran Wayang}

Ontologi sebagai cabang filsafat yang mengkaji tentang hakikat realitas menyisakan berbagai macam persoalan yang menarik untuk

\footnotetext{
${ }^{40}$ Sumarsam, Hayatan Gamelan, Kedalaman Lagu, Teori, Dan Perspektif, 19.

${ }^{41}$ Sumarsam, Hayatan Gamelan, Kedalaman Lagu, Teori, Dan Perspektif, 18-19.

${ }^{42}$ Sumarsam, Hayatan Gamelan, Kedalaman Lagu, Teori, Dan Perspektif, 19.
} 
dikaji. Salah satu persoalan yang menurut peneliti menarik untuk diperbincangkan saat ini adalah persoalan tentang harmoni. Sebelumnya telah disinggung bahwa persoalan harmoni bukanlah persoalan baru di dalam bidang kajian metafisika atau ontologi. Persoalan ini telah mengemuka sejak periode filsafat Yunani Kuno khususnya pada pemikiran Pythagoras yang kemudian dimunculkan lagi oleh Spinoza di dalam pemikirannya tentang harmonia pra estabilita. Persoalan harmoni ini, adalah persoalan yang menarik bagi peneliti karena pembahasan tentang harmoni ini menurut peneliti kurang memadai. Anton Bakker, dalam buku yang berjudul Ontologi atau Metafisika Umum (1992) mengangkat persoalan harmoni sebagai norma ontologis transendental yang mengatasi realitas. Harmoni, namun demikian kurang dijelaskan oleh Bakker dan pembahasannya justru berhenti ketika pembahasan tersebut seharusnya baru dimulai.

Berpijak pada persoalan tersebut, bagian berikutnya akan mengalisis konsep harmoni yang terdapat di dalam pathet pergelaran wayang. Pathet adalah satu unsur yang penting di dalam pertunjukan wayang. Pathet bahkan memegang peranan yang penting di dalam pertunjukan wayang karena pathet menjadi muara dari estetika yang ada pada pertunjukan wayang. Peneliti berasumsi bahwa peran pathet yang sedemikian besar di dalam pertunjukan wayang ini tentu bukan tanpa alasan. Pathet bahkan menjadi patokan atau pedoman bagi seorang dalang atau pemain gamelan di dalam menjalankan perannya. Fenomena ini mengindikasikan peran pathet yang dominan di dalam pertunjukan wayang. Pathet memegang peran yang penting di dalam menjaga struktur pertunjukan wayang tetap pada aturannya. Pembahasan ini, akan membahas tentang konsep harmoni di dalam pathet pergelaran tersebut.

Istilah harmoni adalah istilah yang umum didengar di dalam kehidupan sehari-hari. Ada tiga ruang lingkup wilayah yang biasanya menjadi ruang kajian tentang istilah harmoni tersebut. Pertama, harmoni dikenal di dalam bidang seni musik, misalnya di dalam orkestra. Kajian tentang harmoni di dalam seni musik ini bahkan juga telah menjadi kajian berbagai kalangan akademisi. Kedua, istilah harmoni sering muncul juga di dalam perbincangan tentang etika sosial, yaitu tentang bagaimana menata hubungan antarindividu di dalam masyarakat, sehingga tercipta kondisi sosial yang baik. Ketiga, harmoni juga menjadi perbincangan yang menarik di dalam kajian metafisika atau ontologi. Sebagai contoh adalah persoalan tentang harmoni di dalam pemikiran Anton Bakker. Pembahasan harmoni di dalam penelitian ini sebenarnya lebih dilatarbelakangi atau dipengaruhi oleh persoalan yang ketiga, yaitu harmoni di dalam kajian metafisika atau ontologi. Pembahasan tentang harmoni ini, namun demikian tentu tidak akan mengabaikan dua ruang lingkup kajian lainnya, yaitu harmoni di dalam musik, dan harmoni di dalam kaitannya dengan etika sosial. Dua ruang kajian tersebut tidak dapat ditinggalkan begitu saja karena pembahasan tentang harmoni di dalam penelitian ini akan dianalisis dari pathet pergelaran wayang yang tentunya berkaitan erat dengan permainan orkestra gamelan pengiring pertunjukan wayang. Pembahasan harmoni di dalam lingkup etika sosial, menjadi penting karena dalam pandangan tentang harmoni yang sebenarnya lebih bersifat metafisik tersebut, dalam pandangan masyarakat Jawa pada akhirnya akan bermuara pada etika, yaitu tentang bagaimana manusia kemudian bertindak berdasarkan pengetahuan dan pengalamannya tersebut.

Sebelum mengkaji persoalan harmoni di dalam pathet pergelaran wayang, pertamatama perlu dijelaskan terlebih dahulu makna yang dikandung oleh istilah harmoni tersebut, dan cara yang paling mudah untuk memulai penelusuran atas istilah harmoni adalah dengan melihat arti kata tersebut di dalam kamus. Sesuai dengan yang tertulis di dalam Kamus Besar Bahasa Indonesia, harmoni memiliki beberapa makna, yaitu pernyataan rasa, aksi, gagasan, dan minat; keselarasan; dan keserasian. Berdasarkan arti yang terdapat di dalam KBBI tersebut, tidak banyak yang dapat diketahui tentang makna dari istilah harmoni tersebut, kecuali makna "keselarasan" dan 
"keserasian". Hal ini menyisakan pertanyaan lebih lanjut karena kemudian, arti dari istilah selaras dan serasi tersebut juga perlu dijelaskan. Kembali kepada KBBI, istilah selaras memiliki beberapa arti, yaitu "sama laras"; "setala"; "serasi"; "sesuai"; dan "sepadan". Arti kata serasi, di lain pihak adalah "cocok"; "kena benar"; "selaras"; "sepadan"; dan "harmonis". Berdasarkan arti kamus tersebut, paling tidak dapat ditarik beberapa kesimpulan sebagai berikut. Pertama, harmoni berkaitan dengan relasi atau hubungan. Kedua, unsur, aspek, atau anasir yang terlibat di dalam keadaan harmoni adalah dua atau lebih. Ketiga, harmoni berkaitan dengan kondisi; dan jika mengacu pada arti harmoni di dalam kamus di atas, harmoni adalah sebuah kondisi, yaitu kondisi yang teratur, yang sesuai satu dengan yang lainnya. Harmoni menyiratkan sebuah 'aturan', dan kondisi harmoni tersebut tercipta atau tercapai ketika 'aturan' tersebut dapat terjaga atau terpelihara dengan baik.

Penjelasan tentang harmoni sebagaimana tersebut di dalam kamus tersebut tentunya kurang memadai. Subbab ini oleh karenanya akan menyajikan pandangan tentang harmoni sebagaimana yang tersirat di dalam pertunjukan wayang, khususnya di dalam pathet pergelaran wayang. Pathet dalam hal ini dipilih sebagai objek kajian karena pathet menduduki peran yang sentral di dalam pertunjukan wayang. Pathet tidak hanya berkaitan dengan pembabakan, tetapi berkaitan pula dengan iringan pertunjukan wayang, yaitu orkestra gamelan, yang pada akhirnya juga mempengaruhi sulukan yang dibawakan oleh dalang. Pathet dengan demikian memegang peranan yang penting di dalam membangun suasana pertunjukan wayang. Berpijak pada peran sentral dari pathet pergelaran wayang inilah, peneliti akan membangun pengertian dari konsep harmoni sebagaimana yang terdapat di dalam pertunjukan wayang.

Wayang adalah seni pertunjukan yang sangat kompleks, dalam arti banyak unsur seni yang terlibat di dalam sebuah pertunjukan wayang. Tidak berlebihan karenanya apabila dikemukakan bahwa berhasilnya sebuah pertunjukan wayang dari awal hingga akhir adalah buah dari kerja keras unsur-unsur pendukung pertunjukan tersebut. Untuk membahas pengertian harmoni di dalam pertunjukan wayang, perlu dipahami terlebih dahulu tentang unsur yang terdapat di dalam pertunjukan wayang.

Pertunjukan wayang sebenarnya adalah sebuah media. Wayang dapat dikatakan sebagai sebuah pertunjukan karena wayang memiliki sebuah struktur. Berawal dari jejer pertama hingga tanceb kayon. Sebagai sebuah pertunjukan, wayang memiliki tatanan, memiliki pakem yang menjadi urut-urutan baku di dalam pertunjukan wayang. Pengertian kedua dari wayang adalah wayang sebagai media. Selain struktur pergelaran, sebuah pertunjukan wayang sebenarnya adalah sebuah media, untuk menyampaikan sebuah lakon atau cerita wayang kepada masyarakat penontonnya. Contoh dari hal ini adalah lakon Arjuna Wiwaha, Karna Tandhing, Kresna Duta, dan lain sebagainya. Dua "wilayah" di dalam pertunjukan wayang ini, menurut peneliti perlu dipahami terlebih dahulu karena dua wilayah tersebut akan berkonsekuensi pada pemahaman tentang makna harmoni di dalam pertunjukan wayang.

Analisis pertama tentang pengertian harmoni di dalam pertunjukan wayang dapat dilihat dari wilayah yang pertama, yaitu wilayah struktur pertunjukan wayang. Wayang adalah pertunjukan yang tidak hanya menjadi tontonan masyarakat, melainkan juga mengandung tuntunan, dan terikat pada tatanan atau aturan. Aturan ini, adalah aturan baku di dalam pergelaran wayang yang dimiulai dari talu hingga adegan tanceb kayon dan tarian golek. Tatanan tersebut dapat dikemukakan sebagai berikut.

1. Pertunjukan wayang terbagi menjadi 3 babak. Babak pertama adalah pathet nem; babak kedua adalah pathet sanga; dan babak ketiga adalah pathet manyura. Pembagian pathet ini memiliki konsekuensi yang luas. Pertama, pemain gamelan terutama, harus menyesuaikan gendhing yang dimainkan sebagai pengiring pertunjukan wayang. Sebagai contoh, apabila pathet-nya nem, maka 
gendhing yang harus dimainkan adalah gendhing-gendhing yang memiliki pathet nem. Hal yang sama juga dapat dilihat pada pathet sanga dan manyura. Pada pathet sanga, gendhing-gendhing yang dimainkan adalah gendhing ber-pathet sanga; sedangkan pathet manyura juga akan menampilkan gendhing manyura. Dari segi aturan, demikianlah pathet mendominasi pertunjukan wayang. Kesalahan di dalam penyesuaian terhadap pathet tersebut akan mempengaruhi rasa estetis yang ditimbulkan oleh pertunjukan tersebut.

2. Salah satu aspek penting yang perlu pula di bahas dalam mengkaji harmoni di dalam wayang adalah lakon yang ditampilkan oleh dalang di dalam pertunjukan. Lakon wayang, sebagaimana yang dikemukakan di atas adalah bagian atau anasir yang akan dipisahkan karena digunakan untuk membahas tentang harmoni. Tema tentang harmoni, sebenarnya adalah salah satu tema yang khas di dalam lakon wayang khususnya lakon-lakon carangan. Sebagaimana yang dikemukakan pada uraian sebelumnya, lakon wayang umumnya diawali dengan keadaan harmonis sebuah kerajaan yang tiba-tiba dirusak karena tidak mampunya manusia melawan raksasa. Selama jalannya pertunjukan, tokoh protagonis dari lakon tersebut berjuang untuk mengatasi permasalahan chaos yang ada yang pada akhirnya akan mengembalikan keadaan chaos kepada keteraturan. Pada perspektif lakon ini harmoni karenanya dapat diartikan sebagai sebuah keadaan atau suasana kosmos ketika kekacauan akibat konflik telah berhasil di selesaikan. Harmoni dengan demikian dapat diartikan sebagai sebuah keadaan ketika tidak adanya konflik antaranasir atau dalam bahasa Anton Bakker disebut dengan 'pengada'.

Berbicara tentang persoalan harmoni di dalam pertunjukan wayang sebagaimana dikemukakan di atas, tentu tidak dapat dilepaskan dari persoalan harmoni di dalam tradisi masyarakat Jawa. Alasan utamanya adalah karena pertunjukan wayang adalah bagian dari kebudayaan masyarakat Jawa sehingga sedikit banyak nilai-nilai atau pemahaman masyarakat Jawa ikut berpengaruh di dalam pertunjukan wayang. Termasuk halnya dengan persoalan harmoni ini. Persoalan harmoni, sebenarnya adalah salah satu persoalan yang penting di dalam pemahaman masyarakat Jawa. Persoalan tersebut berhubungan dengan pandangan dunia atau world view masyarakat Jawa yang telah dijelaskan dengan sangat baik oleh Franz Magnis Suseno dalam bukunya yang berjudul Etika Jawa, Sebuah Analisa Falsafi tentang Kebijaksanaan Hidup Jawa (2002). Oleh karena adanya keterkaitan tersebut, penting karenanya untuk membahas tentang persoalan harmoni dalam wayang ini dalam kerangka pandangan masyarakat Jawa tentang harmoni.

Dalam pandangan dunia masyarakat Jawa persoalan harmoni sebenarnya disebut dengan istilah yang berbeda, yaitu prinsip "rukun". Franz Magnis Suseno menyebutnya demikian. Prinsip ini adalah salah satu prinsip yang penting di dalam etika Jawa, di samping prinsip hormat. Pandangan tentang harmoni di dalam pemahaman masyarakat Jawa bermula dari pandangan dunia masyarakat Jawa. Bagi masyarakat Jawa, kosmos, realitas, atau alam semesta adalah misterius. Di dalam alam semesta terdapat banyak sekali "penghuni" dan manusia tidak mengetahui secara persis, di manakah masing-masing realitas tersebut berada. Franz Magnis Suseno memberikan perumpaan untuk hal ini dengan "manusia ibarat berjalan di sebuah ruangan yang penuh dengan barang pecah belah dalam kondisi gelap gulita tanpa penerangan sedikit pun". Keselamatan manusia di ruangan tersebut sangat tergantung pada sejauh mana manusia tersebut bisa melangkah dengan penuh kehatihatian sehingga tidak menimbulkan kekacauan akibat bersinggungan dengan benda yang ada di sekitarnya. Ketika persinggungan dengan benda-benda tersebut tidak terjadi, maka selamatlah manusia tersebut. Di sinilah pandangan tentang harmoni tersebut bermula. Mengacu pada perumpamaan di atas, konsep 
harmoni di dalam pandangan masyarakat Jawa dengan demikian lebih berarti sebagai tiadanya konflik atau persinggungan antara realitas yang satu dengan realitas yang lain. Oleh karenanya, dalam pemahaman etika masyarakat Jawa, penting untuk mencegah agar konflik sebisa mungkin tidak terjadi. Atau paling tidak, manusia harus berusaha semaksimal mungkin agar konflik terbuka tidak terjadi. Oleh karena keadaan rukun dan harmoni adalah segalanya bagi masyarakat Jawa, maka ritus-ritus yang berkaitan dengan upaya untuk menjaga atau memulihkan harmoni adalah peristiwa yang penting. Pertunjukan wayang adalah salah satu bagian dari ritus tersebut.

Sebagai bagian dari budaya Jawa, sudah dapat dipastikan bahwa nilai-nilai budaya Jawa sebagaimana dikemukakan di atas juga dapat dijumpai di dalam pertunjukan wayang. Selama jalannya pertunjukan misalnya, para pemain gamelan dan juga dalang juga harus menyesuaikan dengan pathet pergelaran wayang. Begitu pula dengna adegan-adegan yang ditampilkan oleh dalang. Sebagai contoh, adegan gara-gara adanya adalah pada bagian pathet sanga. Adegan perang brubuh adalah adegan perang yang terdapat pada bagian atau fase pathet manyura. Ketika satu adegan diletakkan tidak sesuai dengan pathet yang ada, maka rasa estetis yang tercipta pun tidak seperti yang diharapkan. Bahkan bisa jadi terkesan bertabrakan. Demikianlah pengertian dari harmoni di dalam pertunjukan wayang. Sebagai catatan penutup, harmoni di dalam wayang dapat diartikan sebagai kondisi ketika semua unsur pergelaran wayang menjalankan fungsinya dengan baik; saling bekerja sama; saling mendukung; saling membantu. Selain itu, harmoni juga mengacu pada sebuah keadaan zero conflict dan atau kondisi yang lebih ringan dari hal tersebut.

\section{Rasa sebagai Prinsip Pertama Harmoni dalam Pathet Pergelaran Wayang}

Ontologi atau metafisika dikenal sebagai cabang filsafat yang mengkaji tentang persoalan hakikat realitas. Kajian ini dapat dikatakan merupakan salah satu kajian yang paling tua di dalam sejarah filsafat Barat karena tema tentang hakikat realitas ini telah menjadi perbincangan filsuf-filsuf Yunani Kuno di periode awal kelahiran filsafat Barat, seperti Thales, Anaximander, Anaximenes, dan berderet nama filsuf lainnya. Seiring dengan perjalanan waktu, persoalan tentang hakikat realitas ini berkembang menjadi semakin kompleks dan pada akhirnya mempengaruhi ruang lingkup kajian ini pada periode-periode filsafat berikutnya. Pada pemikiran Aristoteles misalnya, metafisika dipahami sebagai kajian yang membahas tentang kategori-kategori. Sebutannya adalah sebagai "filsafat pertama". Pada pemikiran Wolff, dipopulerkan istilah ontologi untuk menyebut metafisika yang bersifat umum. Berbagai kritik dan pandangan skeptis terhadap metafisika, tidak dapat dipungkiri memang bermunculan di sepanjang sejarah. Metafisika atau ontologi, namun demikian masih menempati kedudukan yang penting di dalam sistematika ilmu filsafat, sebagai cabang filsafat yang mengkaji tentang hakikat keberadaan realitas.

Perkembangan yang terjadi di dalam perjalanan ontologi pada akhirnya membawa konsekuensi terhadap karakter kajian ini. Seiring dengan munculnya berbagai macam pendapat di dalam ontologi, muncul pendekatan-pendekatan baru yang pada akhirnya memperkaya ruang lingkup kajian ini. Salah satu pendekatan yang dapat digunakan untuk sampai pada pemahaman hakiki tentang realitas tersebut adalah dengan mencari, menyelidiki, atau menggali prinsip pertama atau the first principle dari realitas tersebut. C.A. van Peursen, sebagaimana dikutip oleh Joko Siswanto, berpendapat bahwa ontologi atau metafisika ini adalah cabang filsafat yang mengkaji tentang akar terdalam dari segala yang ada ${ }^{43}$ (Siswanto, 2004: 7). Pencarian atas akar terdalam, the first principle, atau prinsip pertama ini adalah salah satu tema yang menarik di dalam kajian ontologi atau

\footnotetext{
${ }^{43}$ Siswanto, Metafisika Sistematik, 7.
} 
metafisika, meskipun menampakkan karakteristik kajian yang berbeda-beda. Tema ini bahkan sebenarnya bukanlah hal baru di dalam kajian ontologi karena tradisi pencarian prinsip pertama ini, sudah dimulai sejak periode filsafat Yunani Kuno, sebagaimana dikemukakan di atas, yaitu di masa ketika para filsuf era kosmosentris memusatkan kajian filsafat mereka pada persoalan kealaman. Pada masa Yunani Kuno ini, pencarian prinsip pertama mengemuka dalam kajian tentang pencarian arkhe. Jawaban para filsuf pun bermacam-macam. Thales menjawab bahwa prinsip pertama realitas adalah air, Herakleitos menjawab api, Pythagoras menjawab bilangan, dan sebagainya.

Pada periode filsafat kontemporer ini, kajian tentang prinsip pertama ini masih relevan di dalam kajian ontologi atau metafisika. Contohnya dapat dilihat di dalam pendapat C.A. van Peursen di atas. Prinsip pertama sebagaimana dimaksud oleh Van Peursen tersebut, namun demikian tentu perlu dipahami dalam makna yang berbeda dari pencarian prinsip pertama pada masa Yunani Kuno. Pada periode filsafat Yunani kuno, prinsip pertama dipahami sebagai arkhe, yaitu prinsip pertama yang menjadi kekuatan yang mendasari bekerjanya segala yang ada. Prinsip pertama, pada kajian metafisika kontemporer lebih dipahami sebagai hal yang paling mendasar, atau paling fundamental, dan sekaligus menjadi hal yang paling penting dan utama yang membuat segala hal lain menjadi memiliki artinya. Inilah perspektif yang akan digunakan sebagai alat analisis untuk menyelidiki prinsip pertama harmoni di dalam pathet pergelaran wayang ini. Pendapat van Peursen di atas, menginspirasi peneliti untuk melakukan analisis yang sama terhadap persoalan tentang harmoni yang terdapat di dalam pathet pergelaran wayang. Melalui analisis ontologis atas harmoni ini, harapannya akan ditemukan pandangan tentang akar terdalam dari harmoni, yang dapat disimpulkan sebagai prinsip pertama dari harmoni di dalam pathet pergelaran wayang tersebut.

Uraian pada bab sebelumnya telah menjelaskan bahwa pathet sebagai salah satu bagian penting di dalam pertunjukan wayang, memiliki fungsi dan makna filosofis yang tidak hanya terbatas pada pertunjukan wayang saja, tetapi juga berkaitan dengan aspek lain, salah satunya adalah tentang pandangan dunia. Secara fungsional, pathet menempati kedudukan yang penting di dalam keseluruhan pertunjukan wayang karena pathet ibarat menjadi "norma ontologis" yang menentukan unsur-unsur lain di dalam pertunjukan wayang. Pertama, pathet menentukan struktur pertunjukan wayang secara keseluruhan, yang membagi pertunjukan wayang menjadi tiga bagian, yaitu pathet nem, pathet sanga, dan pathet manyura, dengan berbagai macam subadegan yang ada di dalamnya. Kedua, pathet menentukan iringan karawitan yang dimainkan oleh para wiyaga selama berjalannya pertunjukan wayang. Ketiga, pathet menentukan juga tinggi rendah dan warna suara dalang selama menyampaikan catur, baik dalam bentuk ginem, janturan, maupun antawecana. Melihat ketiga peran pathet di dalam pertunjukan wayang tersebut, dapat diketahui bahwa pathet merupakan aspek yang penting di dalam pertunjukan wayang. Pathet bukan hanya dipahami sebagai sebuah struktur tetapi bahkan menjadi norma ontologis yang menentukan atau menjadi faktor utama sehingga struktur pertunjukan wayang tersebut bisa bekerja.

Persoalan tentang prinsip pertama adalah persoalan yang telah mengemuka di dalam kajian filsafat wayang sistematis. Sutrisno, dkk. (2009) dan Tim Filsafat Wayang (2016) telah menemukan bahwa dalam ontologi wayang, prinsip pertama tersebut adalah 'hidup' yang disimbolkan dalam bentuk kayon atau gunungan yang memiliki peran penting di dalam keseluruhan pertunjukan wayang. Temuan tentang hidup sebagai prinsip pertama di dalam ontologi wayang ini menjadi peluang dan sekaligus tantangan di dalam penelusuran tentang ontologi harmoni di dalam pathet pergelaran wayang ini. Temuan tersebut bisa menjadi peluang karena temuan tentang 'hidup' sebagai prinsip pertama di dalam ontologi wayang bisa memberikan petunjuk untuk menemukan prinsip pertama di dalam 
ontologi harmoni pathet pergelaran wayang. Pada saat yang sama, temuan tersebut namun demikian juga menjadi tantangan karena terbuka kemungkinan bahwa prinsip pertama di dalam harmoni pathet pergelaran wayang tersebut justru nantinya mendekonstruksi 'hidup' sebagai prinsip pertama di dalam ontologi wayang.

Peluang dan tantangan di dalam penggalian prinsip pertama harmoni dalam pathet pergelaran wayang di atas pada gilirannya meniscayakan upaya untuk 'menjembatani' diskusi di antara keduanya. Upaya ini dapat ditempuh salah satunya dengan mengembalikan pembahasan tersebut pada akar kultural tradisi wayang, yaitu kebudayaan Jawa. Artinya, baik temuan ontologi wayang maupun ontologi harmoni pathet di dalam pergelaran wayang tersebut harus dapat 'dikembalikan' pada konsep ontologi Jawa secara umum. Pembahasan tentang ontologi Jawa secara holistik dan komprehensif memang belum pernah dilakukan. Referensi untuk mengetahui hal tersebut namun demikian dapat dilihat di dalam penelitian-penelitian tentang budaya Jawa, khususnya yang menganalisis kebudayaan tersebut hingga pada tataran filosofis. Salah satu referensi yang penting di dalam hal ini adalah buku Etika Jawa, Sebuah Analisa Falsafi tentang Kebudayaan Hidup Jawa (2001), karangan Franz Magnis-Suseno.

Pembicaraan tentang harmoni dalam kebudayaan Jawa sebenarnya bukanlah pembahasan yang baru. Tema tentang harmoni, yang mewujud di dalam keselarasan, bahkan dapat dikatakan merupakan salah satu tema terbesar di dalam kajian-kajian tentang kebudayaan Jawa. Kebiasaan masyarakat Jawa untuk menjaga keselarasan baik dalam tataran kehidupan pribadi maupun sosial dengan menghindari terjadinya konflik terbuka menunjukkan bahwa masyarakat Jawa menempatkan keadaan harmoni sebagai situasi yang harus selalu dijaga dan diupayakan sebaik mungkin. Hal ini tidak lain karena latar belakang pandangan dunia Jawa yang fundamental, yaitu adanya asumsi bahwa realitas atau alam semesta berada dalam keadaan teratur atau cosmos dan bukan dalam keadaan chaos. Oleh karena keteraturan tersebut, masyarakat Jawa kemudian menganggap bahwa realitas berjalan dengan pola yang berulang-ulang. Perhitungan tentang astrologi Jawa, semisal dalam bentuk pranata mangsa, neptu, pasaran, petungan, dan sebagainya menunjukkan kepercayaan masyarakat Jawa akan keteraturan dan pola dalam realitas tersebut. Keteraturan tersebut terbangun karena masing-masing anasir realitas menempati 'koordinat'nya, dan menjalankan fungsinya sendiri-sendiri dalam 'struktur' realitas yang besar. Bagi masingmasing anasir tersebut penting untuk menjaga tetap berada pada koordinatnya dan tidak mengganggu anasir lain dengan koordinatnya sendiri. Segala bentuk tindakan yang mengarah pada tindakan merusak keselarasan tersebut adalah tindakan yang harus dihindari, dan sekali keselarasan terganggu, maka kondisi harmoni harus segera dipulihan. Lahirlah kemudian berbagai macam ritus yang dimaksudkan untuk mengembalikan keadaan harmoni tersebut, dan wayang salah satunya lahir sebagai salah satu ritus tersebut.

Mengacu pada pandangan masyarakat Jawa tentang keadaan teraturnya realitas tersebut dapat disimpulkan bahwa sedikit banyak eksistensi pertunjukan wayang juga dipengaruhi oleh pandangan tentang keteraturan realitas tersebut. Menjadi masuk akal karenanya ketika tema tentang harmoni tersebut juga menjadi tema dominan di dalam pertunjukan wayang. Ada beberapa hal dalam wayang yang menunjukkan hal tersebut. Pertama, dalam lakon yang ditampilkan; dan kedua dalam pathet pergelaran wayang. Tema tentang harmoni dapat dijumpai di dalam lakon pertunjukan wayang salah satunya dengan dilihat dari tema lakon wayang yang selalu berusaha mengembalikan kepada keadaan harmoni. Pada uraian tentang representasi pathet di dalam struktur pergelaran wayang telah disebutkan bahwa salah satu kriteria untuk menilai bagus tidaknya sajian lakon wayang adalah konsep mulih, yaitu berhasil tidaknya seorang dalang di dalam mengembalikan keadaan harmoni melalui lakon yang ditampilkan. Hal ini menunjukkan 
bahwa keadaan selaras adalah keadaan yang dituju, diidealkan, dan berusaha diupayakan di dalam pandangan masyarakat Jawa.

Dominasi tema tentang harmoni di dalam kajian tentang kebudayaan Jawa tersebut membuka persoalan baru tentang prinsip pertama dari harmoni tersebut. Apa prinsip pertama yang harus dipenuhi sehingga satu keadaan dapat dikatakan sebagai sebuah harmoni. Jawaban atas persoalan ini dapat dianalisis dari peran pathet di dalam pertunjukan wayang. Pada uraian terdahulu, yaitu tentang pathet sebagai representasi harmoni di dalam pertunjukan wayang, telah disebutkan beberapa konsep yang menjadi ukuran estetika dari beberapa unsur yang terdapat di dalam pewayangan. Berbagai macam konsep estetis tersebut berujung pada satu orientasi estetika pertunjukan wayang, yaitu rasa. Rasa dengan kata lain menjadi muara dari ukuran estetika pertunjukan wayang, baik terkait dengan struktur pertunjukan, iringan karawitan, maupun dengan catur dalang. Rasa dalam pemikiran masyarakat Jawa memang menjadi salah satu tema dominan yang menjadi 'ukuran' atau standar dalam banyak hal bagi orang Jawa. Demikian pula halnya di dalam pertunjukan wayang. Rasa merupakan istilah di dalam bahasa Jawa yang memiliki sangat dalam dan luas, serta menyentuh berbagai macam bidang kehidupan masyarakat Jawa, mulai dari bidang personal, sosial, seni, maupun religi44. Hal yang sama juga dapat dilihat di dalam penelitian Benamou yang menyimpulkan bahwa rasa merupakan orientasi estetik yang paling penting untuk memahami sajian gendhing dalam repertoar karawitan Jawa45. Rasa tersebut di dalam sajian pertunjukan wayang menampati kedudukan yang penting sehingga tidak berlebihan ketika disebutkan bahwa rasa adalah elemen yang membangun estetika pertunjukan wayang. Tanpa adanya rasa tersebut, maka berbagai unsur pertunjukan dan bahkan makna dari pertunjukan itu sendiri kemudian kehilangan maknanya. Mengingat peran rasa yang dominan di dalam bangunan estetika wayang tersebut, dapat dikatakan bahwa prinsip pertama di dalam harmoni pathet pergelaran wayang adalah rasa. Rasa menjadi fundamen dari bangunan pathet dan sekaligus menjadi orientasi dari bangunan pathet itu sendiri. Pathet ada di dalam pertunjukan wayang dalam rangka menjaga rasa tersebut. Berbagai tatanan di dalam pertunjukan wayang harus dijaga juga dalam rangka menjaga rasa tersebut.

\section{SIMPULAN}

Berdasarkan uraian di atas dapat disimpulkan beberapa hal sebagai berikut. Pathet dalam kedudukannya sebagai salah satu unsur di dalam pertunjukan wayang, memiliki beberapa fungsi dan makna. Pertama, pathet merupakan representasi tatanan atau struktur pertunjukan wayang. Kedua, pathet adalah acuan ruang bunyi di dalam karawitan pakeliran. Ketiga, pathet adalah pembangun suasana atau atmosfer pertunjukan wayang. Keempat, pathet adalah pedoman dalang di dalam membangun estetika pertunjukan wayang. Pathet di samping memiliki fungsi sebagaimana disebutkan di atas juga memiliki makna filosofis. Pertama, pathet sebagai manifestasi estetika di dalam pertunjukan wayang. Kedua, pathet sebagai sombolisasi tahap-tahap di dalam kehidupan manusia. Ketiga, pathet sebagai representasi siklus kosmik.

Rasa adalah prinsip pertama harmoni di dalam pathet pergelaran wayang. Rasa tersebut di dalam sajian pertunjukan wayang menampati kedudukan yang penting sehingga tidak berlebihan ketika disebutkan bahwa rasa adalah elemen yang membangun estetika pertunjukan wayang. Tanpa adanya rasa tersebut, maka berbagai unsur pertunjukan dan bahkan makna dari pertunjukan itu sendiri kemudian kehilangan maknanya. Mengingat peran rasa yang dominan di dalam bangunan

45 Marc Benamou, Rasa in Javanese Musical Aesthetics (Michigan: University of Michigan, 1998), 82. 
estetika wayang tersebut, dapat dikatakan bahwa prinsip pertama di dalam harmoni pathet pergelaran wayang adalah rasa. Rasa menjadi fundamen dari bangunan pathet dan sekaligus menjadi orientasi dari bangunan pathet itu sendiri. Pathet ada di dalam pertunjukan wayang dalam rangka menjaga rasa tersebut. Berbagai tatanan di dalam pertunjukan wayang harus dijaga juga dalam rangka menjaga rasa tersebut. Ontologi harmoni dalam pergelaran wayang menunjukkan pandangan yang bercorak monistik, dengan rasa sebagai prinsip utama harmoni di dalam pathet pergelaran wayang tersebut. Rasa ini memiliki dimensi spiritual sehingga ontologi harmoni dalam hal ini bercorak spiritualistik. Dinamika harmoni bergerak dengan hukum empan papan, menuju pada tujuan akhir dari realitas, yaitu kesempurnaan hidup. Ontologi harmoni dalam pathet pergelaran wayang dengan demikian menunjukkan pemikiran yang monistikspiritualistik.

\section{DAFTAR PUSTAKA}

Alisjahbana, Sutan Takdir. Pembimbing Kefilsafat Metafisika. Jakarta: Dian Rakjat, 1967.

Amir, Hazim. Nilai-Nilai Etis Dalam Pewayangan. Jakarta: Pustaka Sinar Harapan, 1991.

Anggoro, Bayu. "WWayang Dan Seni Pertunjukan' Kajian Sejarah Perkembangan Seni Wayang Di Tanah Jawa Sebagai Seni Pertunjukan Dan Dakwah." JUSPI (Jurnal Sejarah Peradaban Islam) 2, no. 2 (2018): 122. https://doi.org/10.30829/j.v2i2.1679.

Bakker, Anton. Ontologi Atau Metafisika Umum. Yogyakarta: Kanisius, 1992.

Bakker, Anton, and Achmad Charris Zubair. Metodologi Penelitian Filsafat. Yogyakarta: Kanisius, 1990.

Benamou, Marc. Rasa in Javanese Musical Aesthetics. Michigan: University of Michigan, 1998.

Cahya. "Nilai, Makna, Dan Simbol Dalam Pertunjukan Wayang Golek Sebagai Representasi Media Pendidikan Budi Pekerti." Panggung 26, no. 2 (2017). https://doi.org/10.26742/panggung.v26i2.17
0.

Cathrin, Shely. "Tinjauan Filsafat Kebudayaan Terhadap Upacara Adat Bersih-Desa Di Desa Tawun, Kecamatan Kasreman, Kabupaten Ngawi, Jawa Timur." Jurnal Filsafat 27, no. 1 (2017): 30-64. https://doi.org/10.22146/jf.22841.

Copleston, Frederick. A History of Philosophy, Volume VI Wolff to Kant. London: Burns and Oates Limited, 1968.

Haryanto, S. Pratiwimba Adhiluhung, Sejarah Dan Perkembangan Wayang. Jakarta: Djambatan, 1988.

Hastanto, S. "The Conce Pt of Pathet in Central Javanese Gamelan Music." Durham University, 1985. http://etheses.dur.ac.uk/1214/.

Kim, Jaegwon, and Ernest Sosa, eds. A Companion to Metaphysics. Oxford: Blackwell Publishing, 1995.

Koentjaraningrat. Kebudayaan, Mentalitas, Dan Pembangunan. Jakarta: Gramedia Pustaka Utam, 2004.

Magnis-Suseno, Franz. Etika Jawa, Sebuah Analisa Falsafi Tentang Kebijaksanaan Hidup Jawa. Jakarta: Gramedia Pustaka Utama, 2001.

Rich, W. N. C. "Nyalap-Nyaur: Model Tatakelola Pergelaran Wayang Jekdong Dalam Hajatan Tradisi JawaTimuran." Humaniora 24, no. 2 (2012): 175-86.

Siswanto, Joko. Metafisika Sistematik. Yogyakarta: Taman Pustaka Kristen, 2004.

Soetarno, Sunardi, and Sudarsono. Estetika Pedalangan. Surakarta: Institut Seni Indonesia (ISI) Surakarta dan CV. Adji, 2007.

Solichin. Falsafah Wayang. Jakarta: Senawangi, 2011.

Sontag, Frederick. Problems of Metaphysics. Scranton: Chandler Publishing Company, 1970.

Sumarsam. Hayatan Gamelan, Kedalaman Lagu, Teori, Dan Perspektif. Surakarta: STSI Press Surakarta, 2002.

Supriyanto, S. "Harmoni Islam Dan Budaya Jawa Dalam Tafsir Alquran Suci Basa Jawi." Wawasan: Jurnal Ilmiah Agama Dan Sosial Budaya 3, no. 1 (June 30, 2018): 17- 
32. https://doi.org/10.15575/jw.v3i1.2578.

Sutrisno, Slamet, Joko Siswanto, Purwadi

Kasidi Hadiprayitno, Mikka Wildha, and Iva

Ariani. Filsafat Wayang. Jakarta:

Senawangi, 2009.
Tim Filsafat Wayang. Filsafat Wayang Sistematis. Jakarta: Senawangi, 2016. 